Agnieszka Łobocka

Wroclaw

\title{
Bibliografia jako element warsztatu informacyjnego badacza sztuki książki
}

Warsztat informacyjny, rozumiany jako zespół różnego typu źródeł wykorzystywanych w pracy naukowej', jest podstawą wszelkiej działalności badawczej. Organizacja warsztatu informacyjnego badacza sztuki książki napotyka na wiele trudności. Zagadnienia historii sztuki książki, $z$ uwagi na bogactwo i różnorodność treści, stanowią interesujący przedmiot badań kilku dyscyplin naukowych. Piękna książka jako całość lub poszczególne jej elementy podlegające ocenie estetycznej, zdobnictwo ksiązki na przestrzeni wieków, mogą znaleźć się w kręgu zainteresowań zarówno księgoznawców, historyków sztuki jak i kulturoznawców.

Ilustracje książki jako narzędzie inicjacji artystycznej dzieci, sztuka książki jako źródło gustów artystycznych, czy zmiany w wyglądzie współczesnej książki pod wpływem nowoczesnych środków przekazu, to tylko niektóre $\mathrm{z}$ problemów, jakimi zajmują się specjaliści $\mathrm{w}$ dziedzinie filologii, pedagogiki, psychologii i socjologii. Badacze ci prezentują różne orientacje teoretyczne i metodologiczne, a stosując wlaściwe dla swojej dyscypliny kryteria, badają odmienne aspekty sztuki ksiazzki. We wszystkich tych badaniach sama ksiazzka, jako obiekt teoretycznej refleksji stanowi przedmiot badań i zarazem źródło.

O ile problematyce źródeł w ogólnej nauce o książce poświęcono wiele opracowań ${ }^{2}$, to rozważania o specyfice bazy źródłowej w badaniach nad sztuką

${ }^{1}$ Por. J. Czachowska, W. Korotaj, Warsztat naukowy historyka literatury w Instytucie Badań Literackich, „Rocznik Biblioteki Narodowej”, 5:1969, s. 315-362; J. Fercz, A. Niemczykowa, Podstawy nauki o ksiqzże, bibliotece i informacji naukowej, Warszawa 1991, s. 186; B. Miśkiewicz, Wstęp do badań historycznych, Poznań 1963, s. 119-120; A. Sitarska, Wspótczesny warsztat wielkich wydawnictw bibliograficznych, „Studia o Ksiażce”, 1:1970, s. 93-116; J. Starnawski, Warsatat bibliograficzny historyka literatury polskiej, Warszawa 1957.

${ }^{2}$ Zob. J. Dunin, O źródlach do spotecznej historii ksiqżki XIX i XX wieku, „Studia o Książce”, 15:1985, s. 149-156; A. Klossowski, Źródła do badań nad dziejami ksiq̨żki na obczyźnie, „Studia o Ksiażce”, 15:1985, s. 87-156; M. Kocójowa, Rozważania nad wyborem podstawy źródlowej $w$ badaniach bibliologicznych (na przykladzie okresu niewoli narodowej), „Studia o Książce”, 15:1985, s. 19-38; K. Migoń, Problematyka źródtoznawcza w bibliologii, „Studia o Książce”, 15:1985, s. 3-18; E. Slodkowska, Czasopisma pieruszej polowy XIX w. jako źródta do badań ksiegoznawczych, „Studia o Książce”, 15:1985, s. 53-68; K. Warda, Inwentarze bibliotek klasztornych jako źródlo do dziejów ksiażki polskiej w XIX w., „Studia o Ksiażce”, 15:1985, s. 115-124; A. Żbikowska-Migoń, Wydawnictwa źródtowe do dziejów książki w Polsce. Stan i potrzeby, „Studia o Ksiażce", 15:1985, s. 39-52. 
książki zajęły do tej pory niewiele miejsca. Zarówno same źródła do badań nad sztuką książki, jak i informacje o nich są w Połsce rozproszone.

Mówiąc o warsztacie informacyjnym badacza sztuki książki, dzięki któremu możliwe będzie odnalezienie dzieł sztuki książki, ich opis, interpretacja oraz ustalenie faktów związanych $z$ ich tworzeniem i funkcjonowaniem, nalezaloby wskazać jego elementy. Zaliczyć do nich należy (zarówno w wersji tradycyjnej - drukowanej, jak też i cyfrowej): wydawnictwa informacyjne (encyklopedie, słowniki, informatory biograficzne, bibliografie, katalogi bibliotek, muzeów oraz wystaw), czasopisma, przekazy biograficzne (pamiętniki, dzienniki, wspomnienia, autobiografie), listy pisane przez twórców i odbiorców dziel sztuki książki oraz wszelkie opracowania.

Bibliografie, najbardziej rozpowszechniony rodzaj wydawnictw informacyjnych, stanowią stały element warsztatu badawczego każdej dyscypliny naukowej.

Przedmiotem badań bibliografii jako nauki, jest książka jako całość, ze szczególnym uwzględnieniem elementów księgoznawczych. Stąd też opisy bibliograficzne zawierają informacje o materiale, $z$ jakiego została wykonana ksiązka, jej oprawa; o objętości, formacie, rodzaju i charakterze tekstu, kompozycji wydawniczej i piśmienniczej, tytulaturze. Zawierają również informacje o aparacie pomocniczym (indeksach, streszczeniach) i zalącznikach, jak również tak istotne dla badacza sztuki książi, informacje o ilustracjach, czy szerzej ukształtowaniu estetycznym edycji.

Warto podkreślić, że oprócz książek wykazy bibliograficzne rejestrują artykuły $\mathrm{z}$ czasopism, które bywają nieocenionym źródłem wiedzy także o funkcjonowaniu dziel sztuki ksiażki. Ponadto bibliografie dostarczają wiadomości na temat produkcji wydawniczej danego państwa, regionu, wskazują, jakie publikacje ukazały się dotychczas na dany temat, a więc i o sztuce książki. Tak więc bibliografie pozwalają odpowiedzieć na pytanie, gdzie szukać informacji o książkach pięknych, rzadkich, bogato ilustrowanych, jak też i ich samych.

Badacz sztuki książki gromadząc materiały do swojej pracy ma do dyspozycji polskie i obce bibliografie o różnym zakresie i zasięgu; bibliografie bibliografii, bibliografie bibliologiczne oraz bibliografie $z$ zakresu historii sztuki.

Ewolucję bibliografii bibliologicznych i główne tendencje ich rozwoju omówila Anna Żbikowska-Migoń w artykule Bibliografie bibliologiczne $i$ bibliotekoznawcze. Rozwój $i$ stan obecny ${ }^{3}$. Jak zauważyla autorka, narodziny bibliografii bibliologicznej przebiegały zgodnie $z$ faktorami wyznaczającymi pojawienie się i okrzepnięcie każdej nowej dyscypliny naukowej, takimi jak: publikacje w danej dziedzinie, czasopisma i spisy bibliograficzne, które pojawiają się wówczas, kiedy kumulacja piśmiennictwa osiąga taki poziom, że przestają być skuteczne indywidualne poszukiwania bibliograficzne badaczy. $Z$ dokonanej prze $Z$ Żbikowską-Migoń analizy konkretnych bibliografii bibliologicznych wynika, że

${ }^{3}$ A. Żbikowska-Migoń, Bibliografie bibliologiczne i bibliotekoznawcze. Rozwój i stan obecny. „Studia o Książce", 1980, t. 10, s. 3-38. 
miaky one najpierw charakter wydawnictw niesamoistnych, publikowanych na lamach czasopism łub w monumentalnych dziełach $\mathrm{z}$ zakresu historii literatury (początkowo bibliologia i historia literatury korzystały ze wspólnego warsztatu informacyjno-bibliograficznego), później przybrały postać spisów bibliograficznych, w których starano się zarejestrować piśmiennictwo wszystkich czasów i krajów, natomiast od drugiej polowy XIX wieku zaczęły pojawiać się bibliografie narodowe bieżące oraz bibliografie dziedzin i zagadnień.

W XX wieku zwiększyła się znacznie liczba bibliografii zagadnieniowych i rozszerzyla się ich tematyka, pojawily się bibliografie analityczne. Nastąpiło przejście od prac indywidualnych do zespołowych, a pracami bibliograficznymi kierują biblioteki narodowe, towarzystwa i organizacje skupiające pracowników ksiązki oraz uczelnie ksztalcące owych pracowników. Nieodzowna stała się współpraca zespołów o międzynarodowym składzie, koniecznym dla opracowania bibliografii o zasięgu międzynarodowym ${ }^{4}$.

Autorka zwrócila również uwagę na innego rodzaju wydawnictwa, które w istotny sposób wzbogacają warsztat informacyjny każdego badacza. Zaliczyła do nich spisy zawartości czasopism i dzieł zbiorowych, drukowane katalogi bibliotek, katalogi okolicznościowych wystaw, publikacje o przeznaczeniu metodyczno-dydaktycznym, przygotowane jako przewodniki na potrzeby studentów czy dysertacje $z$ zakresu bibliologiii ${ }^{5}$. Swój artykul autorka zakończyla apelem o „głębsze zainteresowanie problemami warsztatu bibliograficzno-informacyjnego nauki o książce i bibliotekoznawstwa, gdyż - jak sądzić można - przyczyniłoby się to do lepszej prezentacji owego warsztatu potencjalnym użytkownikom [...], i do wzbogacenia wiedzy teoretycznej o nim, ułatwiłoby też jego twórcom dalsze doskonalenie światowego i krajowego systemu informacji o piśmiennictwie bibliologicznym i bibliotekoznawczym"6. Apel ten można odnieść również do problematyki warsztatu informacyjnego badacza sztuki książki, $z$ uwagi na brak specjalistycznej bibliografii poświęconej tej dyscyplinie. Badacz dziejów sztuki książki w poszukiwaniu materiałów do badań musi korzystać z publikacji rozproszonych w różnych bibliografiach.

\footnotetext{
${ }^{4}$ Tamże, s. 28.

5 Tamże, s. 24-27; celem uzupełnienia wypada wspomnieć bibliografie zawartości czasopism, które ukazały się po opublikowaniu artykułu A. Żbikowskiej-Migoń: M. Klossowska, Bibliografia zawartości Rocznika Biblioteki Narodowej tomy I-XX (1965-1984), Warszawa 1999; S. Kubów, Studia o Ksiqzżce. Bibliografia zawartości tomów 1-10 (1970-1980), Wroclaw 1980, nadb. „Studia o Książce”, t. 10; A. Mendykowa, Roczniki Biblioteczne. Bibliografia zawartości tomów XXI-XXX (1977-1986), Wroclaw 1986, nadb. „Roczniki Biblioteczne", 30:1986, z. 1-2; J. Pelcowa, Bibliografia zawartości Przeglq̨du Bibliotecznego 1927-1976 (R. 1-44), przy wspóludziale I. Gorczyńskiej, Z. Pietrzak i Z. Płuciennik, Wroclaw 1978; J. Sladek, M. Tomecka, Guliwer 1991-2002. Bibliografia zawartości, Katowice 2004; T. Suchar, Roczniki Biblioteczne. Bibliografia zawartości tomów XXXI-XL (1987-1996), Wroclaw 1996, nadb. „Roczniki Biblioteczne”, 40:1996, z. 1-2; H. Zasadowa, Bibliografia zawartości Przeglądu Bibliotecznego 1977-1996 (R. 45-65), Warszawa 1999.

${ }^{6}$ A. Żbikowska-Migoń, Bibliografie bibliologiczne..., s. 29.
} 
Przewodnikami po piśmiennictwie bibliograficznym są retrospektywne i bieżące bibliografie, tzw. spisy drugiego stopnia, czyli bibliografie bibliografii?

Bibliografia bibliografii polskich Wiktora Hahna najważniejsze i największe polskie retrospektywne opracowanie tego typu, obejmuje zestawienia bibliografii od czasów najdawniejszych do 1950 roku, przygotowanych przez autorów polskich i obcych, o ile informatory tych ostatnich dotyczyły zagadnień związanych $z$ Polska. W bibliografii tej znalazly się bibliografie wydawnictw bibliofilskich, bibliografie dotyczące sztuki polskiej i obcej, historii sztuki i szczególnie interesujące $z$ punktu widzenia badacza sztuki książki, bibliografie z zakresu grafiki i rytownictwa. Ponadto badacz sztuki książki odnajdzie w tej bibliografii źródła na temat historii książi, bibliofilstwa, rękopisów, inkunabułów (w tym katalogi rękopisów oraz katalogi i inwentarze inkunabułów), ekslibrisów, a także drukowane katalogi wystaw - książek, ilustracji i ekslibrisów.

Kontynuację Bibliografii bibliografii polskich Hahna stanowi Bibliografia bibliografii polskich 1951-1960 Henryka Sawoniaka'. W informatorze tym zarejestrowane zostały bibliografie rycin oraz bibliografie $z$ zakresu historii sztuki. Zbiory rycin umieścil autor w dziale Ryciny. Natomiast w odniesieniu do ilustracji wydawniczo samoistnych wskazal, że są one wykazywane w odrębnym indeksie alfabetycznym Przewodnika Bibliograficznego. Podobnie autorzy rycin, a więc ilustratorzy, rysownicy, fotografowie, autorzy okładek i układu graficznego wydawnictw, sa wykazywani w osobnym indeksie tej bibliografii. Indeks ilustratorów jest podawany także w oddzielnej grupie w rocznym indeksie $B i b$ liografii zawartości czasopism. Badacz zajmujący się ilustracją książki powinien również sięgnąć do działów Katalogi księgarskie i Katalogi wydawnicze, gdzie opisane są wydawnictwa albumowe. Przedstawień obrazowych poszczególnych osób, miejscowości i regionów należy szukać w dziale Bibliografie specjalne.

Henryk Sawoniak podjął się pionierskiej próby opracowania kompleksowej, retrospektywnej, międzynarodowej dokumentacji z zakresu informacji naukowej, bibliotekoznawstwa i dziedzin pokrewnych ${ }^{10}$. Obejmuje ona ponad 6000 bibliografii, uporządkowanych w 44 działach głównych o różnym zakresie, reprezentujących cale dziedziny (np. Bibliologia, Bibliografia, Rękopisoznawstwo) lub określone zagadnienia (np. Dokumenty specjalne $\mathrm{i}$ ich zbiory $\mathrm{z}$ poddziałami Rękopisy, Ryciny, Stare druki). Istnieją też działy rejestrujące bibliografie o charakterze formalnym Czasopisma $z$ zakresu bibliologii i dziedzin pokrewnych, gdzie występuje jedna bibliografia czasopism bibliofilskich, wydawanych w Europie Zachodniej i USA w latach 60. oraz dzial Osoby (bibliofile, bibliolodzy, historycy książi i pisma).

\footnotetext{
${ }^{7}$ J. Korpała, Bibliografia i bibliograficzna stużba informacyjna. Warszawa 1979. s. 109.

${ }^{8}$ W. Hahn, Bibliografia bibliografii polskich, wyd. 3, Wroclaw 1966.

${ }^{9}$ H. Sawoniak, Bibliografia bibliografii polskich 1951-1960, Wroclaw 1967; rec. S. Skwirowska, „Rocznik Biblioteki Narodowej", 5:1969, s. 394-398.

${ }^{10} \mathrm{H}$. Sawoniak, Międzynarodowa bibliografia bibliografii z zakresu informacji naukowej, bibliotekoznawstwa i dziedzin pokrewnych 1945-1978, Wrocław 1985; rec. M. Dembowska, Międzynarodowa bibliografia bibliografii, „Przegląd Biblioteczny”, 1987, z. 2, s. 185-192; M. Skalska-Zlat, Henryka Sawoniaka Międzynarodowa bibliografia bibliografii, „Przegląd Biblioteczny”, 2003, z. 1/2, s. 170-185.
} 
Bibliografie piśmiennictwa związanego ze sztuką książki znajdują się w dziale 3. Bibliofilstwo. Ekslibrisy oraz 16. Estetyka książki. Ilustratorstwo. Dział Bibliofilstwo. Ekslibrisy rejestruje 71 publikacji na temat kolekcjonerstwa i znaków własnościowych książek, od opracowań ogólnych, po szczegółowe, dotyczące tych zagadnień w krajach europejskich. Związku Radzieckim i Stanach Zjednoczonych. Dział Estetyka ksiazzki. Ilustratorstwo obejmuje 519 bibliografii poświęconych historii zdobnictwa książki i oprawy, iluminatorstwu, ukształtowaniu książek, estetyce książek dla dzieci i młodzieży. Autor uwzględnił równiė̇ wykazy ksiażek najlepiej wydanych oraz zestawienia ksiazzek ilustrowanych, a także książki opracowane graficznie lub ilustrowane przez poszczególnych artystów. $Z$ przeglądu zestawionych przez Sawoniaka bibliografii wynika, że najwięcej opracowań poświęconych jest ilustrowanej Biblii oraz ilustracjom do Alicji w krainie czarów L. Carrolla, Don Kichota Cervantesa, Wojny i pokoju L. Tołstoja, Podróży Guliwera J. Swifta oraz utworów H. C. Andersena, F. Dostojewskiego, E. T. A. Hoffmanna, A. Mickiewicza i J. J. Rousseau. Najwięcej opracowań powstało na temat twórczości W. Blake’a, G. Cruikshanka, P. Lecuire’a i W. Morrisa.

Ponadto Międzynarodowa bibliografia bibliografii... podaje bibliografie zawartości czasopism bibliofilskich, takich jak: „Al'manach Bibliofila”, „Amor di Libro”, „Bibliofilia”, „Biblis”, „Book Collector”, „Bücherstube”, „Bulletin Société des Bibliophiles Liégeois”, „Colophon”, „Exlibris”, „Imprimatur”, „Le Livre et l'Estampe”, „Marginalien”, „Philobiblon”, „Zeitschrift für Bücherfreunde”. W uzupełniających bibliografię aneksach znalazło się jeszcze 16 bibliografii związanych ze sztuką książki, których zasięg chronologiczny wykraczał poza ramy przyjęte $\mathrm{w}$ tytule pracy Sawoniaka. Należy do nich osiem bibliografii i trzy katalogi wystaw, obejmujące zagadnienia na temat estetyki książki, ilustracji i bibliofilstwa w Polsce, które ukazaly się w latach 1925-1933. Pozostałe bibliografie pochodzą $z$ lat 1979-1981 i dotyczą bibliofilstwa francuskiego w latach 1872-1977 oraz ilustracji ksiazzki w Anglii, Niemczech i w Polsce. W sumie Międzynarodowa bibliografia bibliografii... dostarcza wielu cennych informacji o źródłach polskich i obcych, niezbędnych w pracy badacza sztuki ksiązki.

Wydawnictwo K. G. Saur umożliwiło autorowi przystosowanie Międzynarodowej bibliografii bibliografii... dla potrzeb odbiorcy zagranicznego i wydanie nowej wersji poprawionej i uzupełnionej o dodatkowe pozycje i rozbudowane indeksy oraz opublikowanie dalszej części bibliografii za lata 1979-1990. W rezultacie ukazało się w Niemczech, w języku angielskim, dwutomowe opracowanie (każdy $\mathbf{z}$ tomów składa się $\mathbf{z}$ trzech części), o prawdziwie międzynarodowym charakterze, gdyż w przeciwieństwie do wielu zagranicznych europejskich bibliografii, uwzględniające również piśmiennictwo z krajów Azji Wschodniej ${ }^{11}$.

\footnotetext{
${ }^{11} \mathrm{H}$. Sawoniak, International Bibliography of Bibliographies in Library and Information Science and Related Fields, vol. 1, 1945-1978, ed. M. Witt, München 2003; H. Sawoniak, International Bibliography of Bibliographies in Library and Information Science and Related Fields, vol. 2, 1979-1990, with the collaboration of M. Witt, München 1999; rec. A. Bator, „Roczniki Biblioteczne”, 54:2000, s. 252-255.
} 
Dynamika rozwoju nauki o książce, poszerzenie się pola badawczego tej dyscypliny, znaczny wzrost liczby dokumentów w latach 80 . XX wieku, znalazly odzwierciedlenie w budowie International Bibliography of Bibliographies... Pojawilo się wiele działów, nie występujących w Międzynarodowej bibliografii bibliografii..., dotyczących przede wszystkim zastosowania informatyki w dzialalności praktycznej. Nowe działy, takie jak Information services, Information technology, On line services przynoszą wiadomości o komputerowych bazach danych, możliwościach dostępu do nich w trybie online oraz o publikacjach wydanych w postaci CD-ROM. Bogactwo materiałów zamieszczonych w International Bibliography of Bibliographies... daje badaczom ogromne możliwości, przynosząc wiedzę o tradycyjnych i współczesnych źródłach informacji.

O przyroście piśmiennictwa na temat sztuki ksiażki, a co za tym idzie rozwoju tej dyscypliny, pojawieniu się coraz bardziej szczególowych badań, świadczy rozbudowa działów poświęconych poszczególnym zagadnieniom. W International Bibliography of Bibliographies..., tom 2, dzial Art of the Book. Book Illustration obejmuje 18 poddziałów, a więc o pięć więcej w porównaniu do Międzynarodowej bibliografii bibliografii...12. Widać tu wyraźny wzrost liczby publikacji dotyczących ksiazzek ilustrowanych dla dzieci, ich edukacyjnej roli, artystów - twórców książek dla dzieci w różnych krajach. Dział ten rejestruje ogółem 619 bibliografii, a wśród nich katalogi wystaw i spisy najlepiej wydanych książek.

Dzial Bibliophily. Book Collecting zawierający 132 bibliografie rozbudowany został do dziewięciu poddziałów (cztery poddziały w Międzynarodowej bibliografii bibliografii...). Nowe, nie występujące wcześniej działy dotyczą wydawnictw miniaturowych i pras prywatnych. Rozbudowie uległ również dzial History of the book (275 pozycji bibliograficznych, 66 w Międzynarodowej bibliografii bibliografii...), w którym znalazły się bibliografie poświęcone muzeom książki i książkom emblematycznym.

Status odrębnego działu uzyskały Manuscripts, składające się $z$ ośmiu poddziałów. Występują tu opracowania ogólne dotyczące kodykologii, iluminowanych rękopisów oraz ich zbiorów na świecie i w poszczególnych krajach.

$\mathrm{W}$ piśmiennictwie okresu, który obejmuje swym zasięgiem International Bibliography of Bibliographies, pojawiają się opracowania wskazujące na wzrost zainteresowania badaczy sztuką książki Chin i Japonii. W dalszym ciągu w kręgu zainteresowań pozostają kwestie ilustrowanej Biblii oraz ilustracja do utworów literatury pięknej. Do grona autorów książek, które zostały zilustrowane i którzy doczekali się opracowań dołączyli: Ch. Dickens, Ezop, C. Collodi, J. W. Goethe, M. Twain, Wergiliusz, H. Sienkiewicz, E. Puszkin, A. Trollope, J. de La Fontaine. Nadal tematem badań chętnie podejmowanym pozostaje twórczość poszczególnych ilustratorów, a wśród nich W. Blake’a, S. Dali, E. Gilla, K. Greenaway, K. Kollwitz, P. Lecuire'a, M. Pierre-Lucien'a, W. Morrisa i H. Steiner-Praga.

\footnotetext{
${ }^{12}$ Poddział Historia oprawy $z$ Międzynarodowej bibliografii bibliografii... występuje w International bibliography of bibliographies..., t. $2 \mathrm{w}$ dziale History of the book, gdzie ulegl rozbudowie do 3 poddziałów.
} 
Znikoma liczba bibliografii poświęconych książkom ilustrowanym przy pomocy fotografii pozwala przypuszczać, iż jest to jeszcze niezbyt popularny temat badań. Podobnie niewiele jest jeszcze publikacji poświęconych zagadnieniom sztuki ksiazżki XX wieku. Być może wynika to $\mathrm{z}$ niezbyt dużego dystansu jaki dzieli badaczy od tych zagadnień.

Analiza opisów bibliograficznych bibliografii zawartych w dziełach Henryka Sawoniaka pozwala na sformułowanie pewnych wniosków na temat stanu badań nad historią sztuki książki. Daje się zauważyć, że najwięcej publikacji dotyczących problematyki sztuki książki ukazuje się w Europie, w takich krajach jak: Wielka Brytania, Francja, Niemcy, Wlochy i dawny Zwiąek Radziecki, a poza Europa w Stanach Zjednoczonych Ameryki Pólnocnej. Wśród opracowań przeważaja prace jednego autora, poruszające najczęściej tematy szczegółowe, rzadko wykraczające poza problematykę danego kraju. Ogromną popularnością wśród badaczy od lat cieszą się zagadnienia związane $z$ iluminowanymi rękopisami; nie słabnie równiė̇ zainteresowanie książką ilustrowaną. Najwięcej publikacji na ten temat powstaje na Wyspach Brytyjskich, gdzie istnieje bogata tradycja wydawnicza ksiazżek ilustrowanych. Innym popularnym wśród badaczy zagadnieniem jest funkcjonowanie w społeczeństwie ksiązek pięknych, rzadkich, cennych. Bibliografie poświęcone bibliofilstwu często wydawane są we Francji, Włoszech i Niemczech. W dokumentach pochodzących $z$ bylego Związku Radzieckiego wyraźnie widać tendencje do kompleksowego przedstawiania zagadnień sztuki książki.

Wśród zamieszczonych w bibliografiach Sawoniaka publikacji, brak opracowań, w których przedstawiono by rozwój historii sztuki książki w aspekcie międzynarodowym, rzadko też pojawiają się publikacje wskazujące na wzajemne wpływy czy też przenikanie się badań między krajami. Reasumując: brakuje bibliografii bibliografii obejmującej swym zakresem problematykę dyscypliny w szerokim, międzynarodowym aspekcie. Rodzi się pytanie, czy opracowanie takiej bibliografii na obecnym etapie rozwoju historii sztuki książki jest możliwe. Wydaje się, że do tej pory powstało zbyt mało opracowań syntetycznych, obejmujących calość zjawisk. Indywidualne preferencje badaczy koncentrują się raczej wokół wąskich zagadnien. W ciaggu ostatnich lat, od momentu ukazania się International Bibliography of Bibliographies..., tom 2, nie widać wyraźnych zmian w metodzie opracowania bibliografii przydatnych w pracy badacza sztuki książki. W dalszym ciągu są to bibliografie dotyczące wąskich zagadnień, tak jak na przykład bibliografia modlitewników Davida N. Griffithsa ${ }^{13}$, czy bibliografie obejmujące swym zasięgiem określony wycinek czasu, np. Druki kaliskie XIX i I potowy XX wieku ${ }^{14}$.

${ }^{13}$ D. N. Griffiths, The Bibliography of the Book of Common Prayer 1559-1999, London 2003.

${ }^{14}$ E. Andrysiak, K. Walczak, D. Wańka, Druki kaliskie XIX i I potowy XX wieku (1800-1945): bibliografia, Kalisz 2003. 
W Polsce $\mathrm{w}$ minionym okresie nastąpił rozwój bibliografii regionalnych ${ }^{15}$, będących uzupetnieniem krajowego systemu informacji bibliograficznej ${ }^{16}$. Rejestrują one liczne publikacje, nieuwzględnione w bibliografii narodowej. Dostępne są w formie drukowanej, na CD-ROM, w sieciach lokalnych bibliotek i Internecie ${ }^{17}$. Dla badacza sztuki ksiazżki stanowią źródło informacji o funkcjonowaniu pięknej książki w poszczególnych regionach Polski.

Na uwage zasługuje Bibliografia wydawnictw Towarzystwa Miłośników Ksiażki w Krakowie 1922-195218. Powstałe w 1922 roku z inicjatywy m. in. Aleksandra Birkenmajera,Józefa Gryczai Kazimierza Piekarskiego Towarzystwo Miłośników Książki publikowało wydawnictwa bibliofilskie, wydawało rozprawy naukowe, katalogi antykwariatu „Bibliofil Polski”, organizowało wystawy pięknej ksiązki. Prezentowana bibliografia rejestruje w układzie chronologicznym druki Towarzystwa Miłośników Książki w Krakowie $z$ lat 1922-1952, druki okolicznościowe $z$ lat 1923-1952 oraz przedstawia zawartość czasopism „Exlibris” i „Silva Rerum”.

Dodatkowych informacji o podejmowanych w Polsce pracach badawczych dostarczają przygotowane przez Instytut Bibliograficzny Biblioteki Narodowej wykazy polskich bibliografii nieopublikowanych. Obejmują one spisy bibliograficzne pozostające w kartotekach, maszynopisach lub w formie cyfrowej, wykonane w Bibliotece Narodowej, bibliotekach uczelnianych $i$ innych naukowych oraz wojewódzkich i publicznych, a także prace magisterskie. Przegląd tych wykazów umożliwia uniknięcia dublowania wysiłków i umożliwia koordynację prac bibliograficznych w zakresie sztuki książki w skali kraju. Ostatni wydrukowany wyka $\mathrm{z}^{19}$ wymienia $\mathrm{m}$. in. kartoteke Ilustracje $w$ drukach polskich i obcych XVXVIII w. w zbiorach Biblioteki Uniwersyteckiej w Warszawie, Bibliografię exlibrisu polskiego za lata 1950-1976, opracowaną w Wojewódzkiej i Miejskiej Bibliotece w Zielonej Górze oraz prace Edwarda Chwalewika dotyczące ekslibrisów polskich, dostępne w Zakładzie Rękopisów Biblioteki Narodowej: Exlibrisy bibliotek polskich XVI-XIX w., Exlibrisy bibliotek polskich z lat 1901-1944, Exlibrisy lekarzy polskich XVI-XX w. oraz rękopis i maszynopis Inwentarza exlibrisów polskich.

Pewną wskazówką dla badacza sztuki książki odsłaniającą i ukazująca pola badawcze, będące w kręgu zainteresowań instytucji naukowych i dydaktycznych, mogą być bibliografie prac magisterskich, doktorskich i habilitacyjnych.

\footnotetext{
${ }^{15}$ Np. J. Dziok-Strelnik, Bibliografia starych druków lubelskich 1630-1800, Lublin 1997; K. Zawadzki, Bibliografia czasopism warszawskich 1579-1981. t. 1-3, Warszawa 1994-2001.

${ }^{16}$ Zob. A. Żbikowska-Migoń, Bibliografia regionalna - tradycje i perspektywy, w: Narodowe i regionalne serwisy bibliograficzne. Materiały z ogólnopolskiej konferencji nt. „Automatyzacja serwisów bibliograficznych. Bibliografie regionalne, bibliografia narodowa. Stan prac i zamierzenia. Warszawa, 2-4 grudnia 1998 r.", Warszawa 1999, s. 7-17.

${ }^{17}$ E. Stefańczyk, Bibliografie regionalne $w$ bibliotekach publicznych w ostatnich latach, „Poradnik Bibliotekarza", 2003, nr 4, s. 3-8.

${ }^{18}$ B. Szornel-Dąbrowska, Bibliografia wydawnictw Towarzystwa Mitośników Ksiązi w Krakowie 1922-1952, Kielce 2000.

${ }^{19}$ M. Przybysz, D. Urbańska, Wykaz polskich bibliografii nie opublikowanych (planowanych, opra cowanych $i$ ukończonych), wyd. 7, Warszawa 1997. Bibliografia jest jedną z baz Bibliuteki Narodowej, dostępnych w Internecie http://mak.bn.org.pl.
} 
Występują one jako publikacje samoistne ${ }^{20}$, pojawiają się na łamach czasopism $^{21}$ lub są prezentowane na stronach WWW ${ }^{22}$.

Odrębną grupę bibliografii, będąca uzupełnieniem warsztatu informacyjnego, stanowią bibliografie osobowe ${ }^{23}$ lub zespołów osób ${ }^{24}$, rejestrujące dorobek naukowy grup osób związanych $z$ jakąś instytucją książi.

Zbadanie zjawisk zachodzących na ziemiach polskich wymaga często od badacza porównania ich ze zjawiskami występującymi w dziejach sztuki książki na innych obszarach. Dlatego też w swoich dociekaniach badacz sztuki książki musi odwołać się również do piśmiennictwa obcego. Odnalezienie właściwych publikacji umożliwiają mu bibliografie zagraniczne. Szczególnie ciekawą wydaje się być A Bibliography of Printing Edwarda Bigmore'a i Charlesa Wymana ${ }^{25}$, która doczekała się kilku wznowień w postaci reprintów. Opracowana w latach 80. XIX wieku, wydana $z$ drzeworytowymi ilustracjami przedstawiającymi portrety drukarzy, znaki wydawców, scenki z różnych epok, obrazujące działalność warsztatów drukarskich, była dziełem życia antykwariusza Bigmore'a i wydawcy Wymana. Zainteresowany historią drukarstwa Wyman rozpoczął w 1874 roku publikację ilustrowanego miesięcznika „Printing Times and Lithography” i to właśnie czasopismo stało się zalążkiem późniejszej bibliografii. Jej autorzy zgromadzili bogaty material $\mathrm{z}$ zakresu historii sztuki drukarskiej, uzupelniony dokładnymi adnotacjami o losach książek, okolicznościach ich sprzedaży i nabywcach. A Bibliography of Printing dostarcza badaczowi dziejów sztuki książki źródeł pozwalających na odtworzenie losów pięknie wydanych książek.

Innym cennym źródlem do badań historii sztuki książki w krajach anglojęzycznych jest reprint $A$ Descriptive Bibliography of the Most Important Books in the English Language Relating to the History of Engraving and Collecting of Prints

${ }^{20}$ P. Litwiniuk, Bibliografia prac magisterskich, doktorskich i habilitacyjnych wykonanych $w$ Instytucie Bibliotekoznawstwa 1961-1987, Wrocław 1997: tenże, Bibliografia prac magisterskich, doktorskich $i$ habilitacyjnych wykonanych $w$ Instytucie Bibliotekoznawstwa 1988-1997, Wroclaw 1997.

${ }^{21}$ Wykazy prac wykonanych w Katedrze Bibliotekoznawstwa i Informacji Naukowej WSP w Bydgoszczy publikowane są od 1994 roku w czasopiśmie „Studia Bibliologiczne”, Zeszyty Naukowe WSP w Bydgoszczy.

${ }^{22}$ Od 1 lipca 1998 roku Biblioteka Niemiecka - Deutsche Bibliothek gromadzi i udostępnia w trybie online prace doktorskie $\mathbf{i}$ habilitacyjne $\mathrm{http} / / / \mathrm{www}$. ddb.de; inne adresy internetowe umożliwiające zapoznanie się $\mathrm{z}$ tezami prac: http://www.umi.com/hp/Products/Dissertation.html; http://www. umi. com/cresearch/galery/main; informacje o pracach magisterskich Instytutu Informacji Naukowej i Bibliotekoznawstwa Akademii Pedagogicznej w Krakowie http://wbp.kraków.pl/cgi-bin/mak.wwr2/makwww.exe; Instytutu Bibliotekoznawstwa i Dziennikarstwa Akademii Świętokrzyskiej w Kielcach http:// ibib.pu.kielce.pl.

${ }^{23}$ S. Kojarska, Bibliografia prac Zofii Ameisenowej, „Biuletyn Biblioteki Jagiellońskiej”, 1966, nr 1, s. $10-17$.

${ }^{24}$ Bibliografia prac pracowników Instytutu Informacji Naukowej i Bibliotekoznawstwa Uniwersytetu Wroclawskiego 1952-1998 http://www.ibi.uni.wroc.pl/bibliokn/bibgr.htm.

${ }^{25}$ E. C. Bigmore, C. W. H. Wyman, A Bibliography of Printing with Notes and Illustrations, $3^{\text {rd }}$ ed., London 2001. 
Howarda C. Levisa ${ }^{26}$. Intencją autora wydanej na początku XX wieku bibliografii, było przedstawienie rozwoju literatury angielskiej na temat zagadnień związanych $z$ książkami rzadkimi ${ }^{27}$. W 26 rozdziałach znajdują się opisy bibliograficzne publikacji dotyczących rytownictwa, książek ilustrowanych, ekslibrisów, kolekcji prywatnych, zbiorów w bibliotekach i muzeach, biografii i monografii artystów, katalogów prac, a także dzialalności i wydawnictw towarzystw bibliofilskich. Badacz określonego rodzaju ilustracji znajdzie w A Descriptive Biblography of the Most Important Books... informacje o japońskiej książce ilustrowanej, ilustracjach do książek o sporcie, militariach, książkach zawierających karykatury lub portrety. W bibliografii znalazły się także źródła na temat ilustracji ksiażki we Francji w XVIII wieku. Badacz śledzący motyw książki w literaturze pięknej, uzyska wskazówki na temat angielskiej poezji i pieśni o drukarzach i rytownikach. Ponadto autor bibliografii wskazal katalogi wydawnictw, posiadające adnotacje o ważnych dla kultury anglojęzycznej książkach i informacje biograficzne o ich twórcach. W całości bibliografia Levisa stanowi kompletne źródło informacji prezentujące różne aspekty funkcjonowania pięknej książki.

Ciekawym przykładem bibliografii, niezwykle przydatnym w pracach badacza sztuki książki, jest adnotowana International Bibliography of Ant Librarianship Pauli $\mathrm{A}$. Baxter ${ }^{28}$. Rozwijające się od lat 60 . XX wieku art libraries, gromadzące $\mathrm{w}$ swych zbiorach wydawnictwa $\mathrm{z}$ zakresu sztuki oraz książki cenne, rzadkie, piękne, są ważnym warsztatem pracy dla wielu badaczy. Przewodnikiem po zbiorach tych bibliotek na całym świecie jest opracowanie Baxter, będące pierwszym tego typu informatorem. Autorka zaprezentowała i w rzetelny sposób omówiła publikacje dotyczące zbiorów specjalnych i kolekcji rzadkich książek, wydawnictw muzeów i galerii oraz katalogów wystaw.

$\mathrm{Na}$ gruncie polskim rolę przewodników informujących o publikacjach muzeów - książkach, czasopismach, katalogach wystaw - mogą pełnić bibliografie zawartości wydawnictw muzeów ${ }^{29}$.

W warsztacie informacyjnym badacza sztuki książki nie może zabraknąć bibliografii historii sztuki, prezentujących materiały ułatwiające zrekonstruowanie procesu dzialań artystycznych, idei wpływających i kształtujących powstanie książki - dzieła sztuki. Janina Wiercińska w artykule Bibliografie historii sztuki zaznaczyła, że nie istnieje kompletna, skumulowana bibliografia historii

${ }^{26}$ H. C. Levis, A Descriptive Bibliography of the Most Important Books in the English Language Relating to the History of Engraving and Collecting of Prints, Folkstone 1974.

${ }^{27}$ Tamże, s. XI.

${ }^{28}$ P. A. Baxter, International Bibliography of Art Librarianship, München 1987.

${ }^{29}$ G. Kurkowa, Bibliografia zawartości wydawnictw muzeów w Polsce za lata 1978-1982. Druki zwarte i ciagłe, Warszawa 1997; G. Kurkowa, B. Pawłowska-Wilde, Bibliografia zawartości wydawnictw muzeów w Polsce za lata 1983-1972, Warszawa 1999; M. Laskowska, Bibliografia zawartości uydawnictw muzeów polskich 1945-1964, „Muzealnictwo”, 1964, nr 17, s. 103-143; M. Laskowska, Bibliografia zawartości wydawnictw muzeów w Polsce za lata 1973-1977. Druki zwarte i ciggle, Warszawa 1986; J. Mazurkiewicz, Wydaunictwa muzeów historyczno-artystycznych (1945-1962), „Rocznik Muzeum Toruńskiego”, 1964, t. 1, z. 4, s. 32-56; A. Ryszkiewicz, Wydawnictwa artystyczne muzeów polskich w latach 1962-1963. „Muzealnictwo", 1966, nr 13, s. 170-180. 
sztuki, są natomiast liczne prace rejestrujące dorobek badaczy z zakresu teorii i historii sztuki oraz estetyk ${ }^{30}$. Autorka omówiła najważniejsze bibliografie i inne wydawnictwa informacyjne, do których można sięgnąć w przypadku zainteresowania określonym zagadnieniem czy sztuką danego kraju, regionu lub miejscowości. Wiercińska wskazała, iż w skompletowaniu literatury pomocne będa podręczniki zaopatrzone $\mathrm{w}$ bibliografię przedmiotu oraz czasopisma, publikujące na swych łamach zestawienia bibliograficzne, dotyczące różnych tematów.

Przewodnikiem po wydawnictwach $z$ zakresu sztuki są materiały bibliograficzne opracowane przez asystentów profesora Jerzego Szablowskiego, prowadzącego od połowy lat 60 . ubieglego wieku zajęcia $z$ bibliografii dla studentów pierwszego roku historii sztuki Uniwersytetu Jagiellońskiego. Przejęcie tych ćwiczeń w następnych latach przez Adama Małkiewicza i Jana Ostrowskiego doprowadzilo do stałej aktualizacji, uzupełnienia i poszerzenia notatek opracowanych przez Szablowskiego, a następnie do ich powielenia ${ }^{31}$. W rezultacie powstało podręczne kompendium, umożliwiające uzyskanie podstawowych informacji i dotarcie do literatury przedmiotu. Znajduje się w nim zestaw bibliografii, słowników i encyklopedii oraz opracowań ogólnych i szczegółowych, polskich i obcych, dotyczących $m$. in. ikonografii i ornamentyki, a także bibliografie zawartości czasopism i wykaz aktualnie ukazujących się periodyków poświęconych sztuce. Materiały Małkiewicza i Ostrowskiego pozwalają na uzupełnienie i wzbogacenie wiedzy na temat zjawisk występujących w sztuce, obowiązującej terminologii, przydatnej zwłaszcza badaczom, nie będącym $z$ wykształcenia historykami sztuki.

Badania nad sztuką książki prowadzone przez bibliologów i historyków sztuki wymagają od badaczy ciągłego sięgania po aparat naukowy, specyficzny dla tych dziedzin. Jednym $z$ warunków rozwoju historii sztuki książki jest współpraca przedstawicieli obu nauk ${ }^{32}$. Materiały interesujące zarówno bibliologów jak i historyków sztuki zawiera Polska Bibliografia Sztuki 1801-1944³3. W jej pierwszym tomie, opracowanym w Instytucie Sztuki PAN, występuje dział Iluminatorstwo. Obejmuje 80 opracowań; w przeważającej części są to artykuły opublikowane na łamach „Sprawozdań Komisji do Badania Historii Sztuki w Polsce”, „Bulletin de la Société Française de Réproduction de Manuscrits à Peintures" oraz „Sprawozdań Towarzystwa Naukowego we Lwowie”.

Najczęstszym tematem prezentowanych prac są miniatury: jednego rękopisu (np. Miniatury w Antyfonarzu katedry gnieźnieńskiej poz. 1273, Miniatury modlitewnika króla Wtadystawa poz. 1314); zespołów rękopisów znajdujących się w zbiorach bibliotek (np. Miniatury tynieckich ksiag liturgicznych w bibliotece Uniwersytetu we Lwowie poz. 1290, O iluminowanych mszatach $i$ graduatach

\footnotetext{
${ }^{30}$ Wiercińska J., Bibliografie historii sztuki, w: Wstęp do historii sztuki, t. 1: Przedmiot, metodologia, zawód, red. P. Skubiszewski, Warszawa 1973, s. 385-394.

${ }^{31}$ A. Malkiewicz i J. K. Ostrowski, Wstęp do historii sztuki. Materiaty bibliograficzne, wyd. 3 uzup. Kraków 1995.

${ }^{32}$ J. Wiercińska, Bibliografie historii sztuki, s. 392.
} 
Biblioteki Kapitulnej Wtoctawskiej poz. 1292, Kodeksy z miniaturami w zbiorach Ptocka, Sandomierza $i$ Wtoctawka poz. 1266) lub rękopisów powstałych na danym terenie (np. miniatury rękopisów Ślaskich XIV wieku poz. 1286, Miniatury ślqaskie do końca XIV wieku, poz. 1287, Iluminowane karty antyfonarzy tynieckich, poz. 1289). Jak wykazuje analiza zawartości tej bibliografii najchętniej badanymi rękopisami były: Psatterz Floriański i Kodeks Baltazara Behema.

Drugi tom Polskiej bibliografii sztuki rejestruje publikacje $z$ pogranicza sztuki $\mathrm{i}$ innych dyscyplin wiedzy ${ }^{34}$. Jak piszą w przedmowie autorki, chodzilo im o to, by „uwzględnić wszystko, co dotyczy druków zasługujących na uwagę badacza spraw sztuki i co mówi o tych drukach i oficynach, dla których poziom artystyczny byl sprawą równie ważną jak treść ksiąg"35.

Chociaż Polska bibliografia sztuki... powstała przede wszystkim z myślą o historykach sztuki, badacze sztuki ksiażki znajda w niej bogate informacje o pracach przydatnych w studiach nad różnymi elementami składowymi edycji, ukazujące obraz zainteresowań różnymi problemami badaczy polskich i obcych, zajmującymi się dziejami sztuki książki w XIX w. i pierwszej polowie XX w. Publikacje związane ze sztuką książki autorki zebrały w dzialach: Rysunek; Grafika; Sztuka książki i druku (poddziały: Ujęcia ogólne; Wiek XVI-XVIII; Od 1800-1900 r.; Od 1901 do 1944 r.; Szkolnictwo; Stowarzyszenia i ugrupowania: a. Grafików; b. Milośników książek); Ekslibris; Wystawy i Artyści. Najwięcej prac poświęconych zostało zagadnieniom dotyczącym drzeworytu i litografii $\mathrm{i}$ ich związków $z$ drukarstwem. Często podejmowanym tematem byly ilustracje - ich poziom artystyczny i znaczenie. W latach 20 . i 30. XX wieku na plan pierwszy wysunęla się problematyka pięknej książki, rozumianej jako „zespół czynników materialnych, papieru, czcionek, ilustracji światłodrukowych, druku i oprawy"36. W tytułach prac występowały wówczas takie określenia jak: kultura estetyczna książki, zewnętrzne piękno książki, szata książki, zdobnictwo graficzne, estetyczna kompozycja ksiąziki, kultura druku, druki piękne, szata ilustracyjna, sztuka w sztuce drukarskiej. Równie często podejmowane były zagadnienia dotyczące ekslibrisów, zarówno te wspólczesne badaczom jak i związane $z$ przeszlością. Powstawały prace, w których starano się ująć całość zjawisk polskiego ekslibrisu (O ekslibrisach polskich, ich twórcach $i$ wykonawcach poz. 784, Inwentarz ekslibrisów polskich poz. 819); zaprezentować zbiory znaków własnościowych (Biblioteki na Podolu $i$ ich ekslibrisy poz. 793, Dziat polski w zbiorze ekslibrisów British Museum poz. 802); poszczególne ich rodzaje (ekslibrisy herbowe poz. 806, 812, muzyczne poz. 821, myśliwskie poz. 810); znaki pewnych grup społecznych (antykwariuszy i bibliofilów poz. 816, 826) lub osób prywatnych (poz. 829, 830, 835, 836). Liczba zamieszczonych artykułów na temat organizowanych konkursów

${ }^{33}$ J. Wiercińska, M. Liczbińska, Polska bibliografia sztuki 1801-1944, t. 1: Malarstwo polskie, cz. 1: Prace ogólne, historia, malarze A-K, Wroclaw 1975; cz. 2: Malarze L-Z, Wrocław 1976.

${ }^{34}$ J. Wiercińska, M. Liczbińska, Polska bibliografia sztuki 1801-1944, t. 2: Rysunek, grafika, sztuka ksiq̨żki i druku, Wrocław 1979.

35 Tamże, s. VIII.

${ }^{36}$ Z tytułu opracowania B. Lenarta, Piękna książka jako..., Wilno 1928/1929. 
na wykonanie ekslibrisu, pozwala przypuszczać, iż na początku XX wieku były one często oglaszane, a artyści chętnie brali w nich udzial. Równie często organizowane były wystawy polskich książek, ilustracji i ekslibrisów, nie tylko w kraju, ale i za granica.

Znaczna część drugiego tomu Polskiej bibliografii sztuki... poświęcona jest twórczości artystów - grafików i malarzy. Ogromnym zainteresowaniem badaczy cieszyły się prace M. E. Andriollego, D. Chodowieckiego, S. Ostoi-Chrostowskiego i S. Wyspiańskiego. Oprócz tego wiele jest opracowań dotyczących działalności rytowników (napisanych głównie w XIX wieku) oraz artykułów o ilustracjach artystów polskich do utworów literatury pięknej. Autorami omawianych publikacji byli sami artyści, pisarze, także bibliolodzy, historycy sztuki, co może świadczyć o dużym zainteresowaniu sztuką książki w różnych kręgach badaczy, teoretyków i praktyków edytorstwa.

Bibliografia polskiej historii sztuki ${ }^{37}, \mathrm{z}$ zalożenia bieżąca, publikowana na lamach „Rocznika Historii Sztuki”, rejestruje piśmiennictwo $z$ zakresu teorii i historii sztuki, powstałe po 1944 roku. Obejmuje ona także publikacje na temat sztuki książki, ekslibrisów i drukarstwa. Znalazły się one w tym samym dziale, co opracowania na temat grafiki (dzial Rysunek. Grafika. Sztuka książki i pisma). W bibliografii za lata 1969-1972 zajmują odrębny dzial (Sztuka książki. Ekslibris. Drukarstwo), w tych latach bowiem pojawilo się wiele materiałów dotyczących grafiki, konieczne stało się więc utworzenie osobnego działu.

Wydawnictwa dotyczące sztuki książki autorzy bibliografii uszeregowali według następującego schematu: Opracowania ogólne, Polska (w podziale na okresy chronologiczne) i Inne kraje.

Zarejestrowane w Bibliografii polskiej historii sztuki publikacje wskazują stałe zainteresowanie badaczy sprawami ekslibrisów i ilustracji. Obok opracowań przygotowanych przez bibliologów znajdują się artykuły historyków sztuki opublikowane w „Biuletynie Historii Sztuki”, „Roczniku Historii Sztuki”, „Sprawozdaniach Polskiej Akademii Umiejętności”, w czasopismach „Projekt” i „Twórczość”. Teksty zamieszczone w tym ostatnim miesięczniku dotyczyły przede wszystkim problemów ilustracji utworów literatury pięknej.

Zaprezentowane przykłady nie wyczerpują ogromnego bogactwa i różnorodności bibliografii, maja one jedynie wskazać na możliwości i kierunki poszukiwań literatury przedmiotu do badań podejmowanych przez badaczy sztuki książki. Omawiane wydawnictwa pozwalają na wyodrębnienie tych obszarów badawczych, które od lat, niezmiennie pozostają w kręgu zainteresowań badaczy

\footnotetext{
${ }^{37}$ N. Cieślińska, A. Rudzka, Bibliografia polskiej historii sztuki za lata 1969-1970, „Rocznik Historii Sztuki”, 12:1981, s. 265-375; H. Fruba, A. Rudzka, Bibliografia polskiej historii sztuki za lata 1971-1972, „Rocznik Historii Sztuki”, 13:1981, s. 237-366. A. Ryszkiewicz, J. Wiercińska, Bibliografia historii sztuki 1945-1968, „Rocznik Historii Sztuki”, 4:1964, s. 215-337; tychże, Bibliografia historii sztuki 1945-1968, „Rocznik Historii Sztuki”, 5:1965, s. 213-307; tychże, Bibliografia historii sztuki 1945-1968, „Rocznik Historii Sztuki”, 6:1966, s. 303-400; tychże, Bibliografia historii sztuki 1945-1968, „Rocznik Historii Sztuki”, 7:1969, s. 317-378; tychże, Bibliografia historii sztuki 1945-1968, „Rocznik Historii Sztuki”, 9:1973, s. $337-468$
} 
(rękopisy iluminowane, ilustracje, ekslibrisy) oraz tych, które nie cieszą się dużą popularnością (fotografia w książce, sztuka książki drugiej połowy XX wieku, sztuka książki Azji i innych krajów orientalnych). Wydaje się konieczne skumulowanie wszystkich rozproszonych opracowań na temat sztuki książki, w jedną retrospektywną bibliografię historii sztuki ksiażki, co przy obecnym poziomie rozwoju techniki informatycznej możliwe jest do zrealizowania. Konieczne te $\dot{z}$ jest prowadzenie prac nad bieżącymi, narodowymi i międzynarodową bibliografią sztuki książki. Powstanie tych bibliografii byłoby znacznym ułatwieniem w dociekaniach badawczych i kolejnym etapem na drodze ksztaltowania się i rozwoju dyscypliny. 